\title{
'Candidatus Liberibacter europaeus' sp. nov. that is associated with and transmitted by the psyllid Cacopsylla pyri apparently behaves as an endophyte rather than a pathogen
}

Noura Raddadi, ${ }^{1}$ Elena Gonella, ${ }^{1}$ Caterina Camerota ${ }^{1}$, Alan Pizzinat, ${ }^{1}$ Rosemarie Tedeschi, ${ }^{1}$ Elena Crotti, ${ }^{2}$ Mauro Mandrioli, ${ }^{3}$ Piero Attilio Bianco, ${ }^{4}$ Daniele Daffonchio ${ }^{2 *}$ and Alberto Alma ${ }^{1 * *}$ ${ }^{1}$ Dipartimento di Valorizzazione e Protezione delle Risorse Agroforestali (DIVAPRA), Università degli Studi di Torino, via L. da Vinci 44, 10095 Grugliasco (TO), Italy.

${ }^{2}$ Dipartimento di Scienze e Tecnologie Alimentari e Microbiologiche (DISTAM), Università degli Studi di Milano, via Celoria 2, 20133 Milan, Italy.

${ }^{3}$ Dipartimento di Biologia (DB), Università degli Studi di Modena e Reggio Emilia, I-41125 Modena, Italy. ${ }^{4}$ Dipartimento di Produzione Vegetale (DIPROVE), Università degli Studi di Milano, 20133 Milan, Italy.

\section{Summary}

'Candidatus Liberibacter spp.' cause serious plant diseases. 'Candidatus Liberibacter asiaticus', 'Ca. L. americanus' and ' $\mathrm{Ca}$. L. africanus' are the aetiological agents of citrus greening (Huanglongbing) in Asia, America and Africa. 'Candidatus Liberibacter solanacearum' causes diseases in Solanaceae in America and New Zealand. All four species are vectored by psyllid insects of different genera. Here, we show that the pear psyllid pest Cacopsylla pyri (L.) hosts a novel liberibacter species that we named ' $\mathrm{Ca}$. Liberibacter europaeus'. It can bloom to high titres in the psyllid host, with more than $10^{9} 16 \mathrm{~S}$ rRNA gene copies per individual. Fluorescent in situ hybridization experiments showed that ' $\mathrm{Ca}$. L. europaeus' is present in the host midgut lumen, salivary glands and Malpighian tubules. 'Candidatus $\mathrm{L}$. europaeus' has a relatively high prevalence $(>51 \%)$ in $C$. pyri from different areas in the Piedmont and Valle d'Aosta regions in Italy and can be transmitted to pear plants in experimental transmission trials. However, even though high titres of the bacterium (more than $10^{8} 16 \mathrm{~S}$ rRNA gene

Received 15 March, 2010; accepted 11 August, 2010. For correspondence. *E-mail daniele.daffonchio@ unimi.it; Tel. (+39) 250319117

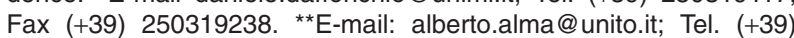
116708534; Fax (+39) 116708535. copies $\mathrm{g}^{-1}$ of pear plant tissue) could be detected, in the pear tissues no specific disease symptoms could be observed in the infected plants over a 6-month period. Despite liberibacters representing potential quarantine organisms, ' $\mathrm{Ca}$. L. europaeus', first described in Italy and Europe, apparently behaves as an endophyte rather than a pathogen.

\section{Introduction}

Huanglongbing (HLB, from the Chinese yellow dragon disease) is a destructive disease of citrus plants that is caused by Gram-negative, phloem-restricted nonculturable Alphaproteobacteria belonging to the candidate genus 'Candidatus Liberibacter' (Bové, 2006 and references therein). To date, three species from HLB liberibacters infecting citrus plants have been recognized: 'Ca. Liberibacter asiaticus', 'Ca. L. africanus' and 'Ca. L. americanus'. Although ' $\mathrm{Ca}$. L. africanus' is found only in Africa, 'Ca. L. asiaticus', first described in Asia, has also been found in the Americas together with ' $\mathrm{Ca}$. L. americanus' (Teixeira et al., 2005; Lopes et al., 2009). In nature, the transmission of these quarantined (in Europe) pathogens from plant to plant is carried out by citrus psyllids: Diaphorina citri (Kuwayama) in Asia and America and Trioza erytreae (Del Guercio) in Africa. Recently, another psyllid species, the potato/tomato psyllid Bactericera cockerelli (Sulc), has been reported to host and transmit a fourth liberibacter species ' $\mathrm{Ca}$. Liberibacter solanacearum'. It has been reported to cause psyllid yellows and zebra chip diseases on solanaceous plants in New Zealand and America (Hansen et al., 2008; Abad et al., 2009; Liefting et al., 2009; Secor et al., 2009).

Duan and colleagues (2009) showed that ' $C a$. L. asiaticus' is the dominant bacterium associated with $D$. citri, three and half orders of magnitude more abundant than the primary endosymbiont 'Candidatus Carsonella ruddii'. They suggested that the liberibacter behaves as a symbiont in the psyllid host and thereby is capable of a double lifestyle, pathogenic in the plant and symbiotic in the insect (Duan et al., 2009).

To date, the Mediterranean area is still free of the HLB, psyllid yellows and zebra chip diseases as well as the 
three corresponding vectors (Teixeira et al., 2008). However, other psyllid species living on several temperate fruit trees and vegetables are present (Conci et al., 1993; Tedeschi et al., 2002; Micheletti et al., 2005; Ben Khalifa et al., 2007).

To the best of our knowledge, there have been no reports in the literature dealing with the association of liberibacters with insect hosts other than psyllids. This evidence suggests that psyllids are important insect hosts of these pathogenic bacteria. However, no investigations have yet checked if or how other psyllids can host liberibacters or studied the diversity of liberibacters in different psyllid species.

The objective of this study was to investigate if liberibacters are associated with the psyllid species Cacopsylla pyri that is known as an important vector of 'Candidatus Phytoplasma pyri', the cell wall-less Mollicutes that causes pear decline (PD) in pear trees (Seemüller and Schneider, 2004). We characterized the microbiota associated with the psyllid and showed for the first time that a new liberibacter species, here named ' $\mathrm{Ca}$. Liberibacter europaeus', is hosted by $C$. pyri and can be transmitted to pear plants. 'Candidatus L. europaeus' is particular because it can infect pear plants at high titre but without causing any apparent specific symptoms.

\section{Results}

Characterization of the bacterial community associated with adults of $\mathrm{C}$. pyri

The diversity of symbiotic bacteria associated with $C$. pyri individuals collected from pear orchards in Valle
d'Aosta and Piedmont regions, north-western Italy, was analysed by $16 \mathrm{~S}$ rRNA gene PCR-DGGE, using as template DNA isolated from whole single individuals. We first used this technique to analyse $36 \mathrm{C}$. pyri individuals (19 males and 17 females). An example of the DGGE profiles is shown in Fig. 1. Some variability in the community profiles was observed between different individuals, even though certain bands were conserved among almost all the individuals examined, such as bands $A 1$ and $\mathrm{A} 3$ that were detected in 15 and 14 of the 18 individuals examined respectively (Table 1). Moreover, the intensity of the different bands ranged from intense to very faint. However, PCR-DGGE cannot be used for the quantitative estimation of the target templates, and so a large difference in the intensity among bands suggests that different cell amounts per individual of the different symbionts were observed. The sequences obtained from the different bands excised from the DGGE gels are presented in Table 1 together with their closest relatives found by BLAST search. Band A1 showed $100 \%$ identity with ' $\mathrm{Ca}$. C. ruddii' the primary endosymbiont of psyllids (Spaulding and von Dohlen, 1998; Thao et al., 2000; Clark et al., 2001), whereas band A2 showed 100\% identity with the PD phytoplasma 'Ca. P. pyri' (Seemüller and Schneider, 2004). Band A3 showed $98 \%$ identity with both the secondary endosymbiont of Cacopsylla pyricola (Förster) (Spaulding and von Dohlen, 2001) and the Arsenophonus endosymbiont of Trichobius yunkeri Wenzel (Trowbridge et al., 2006). Arsenophonus has been reported as a secondary endosymbiont of psyllids such as D. citri (Subandiyah et al., 2000a). Band A5 had $100 \%$ identity with Ralstonia sp. (AB503703). Bacteria of

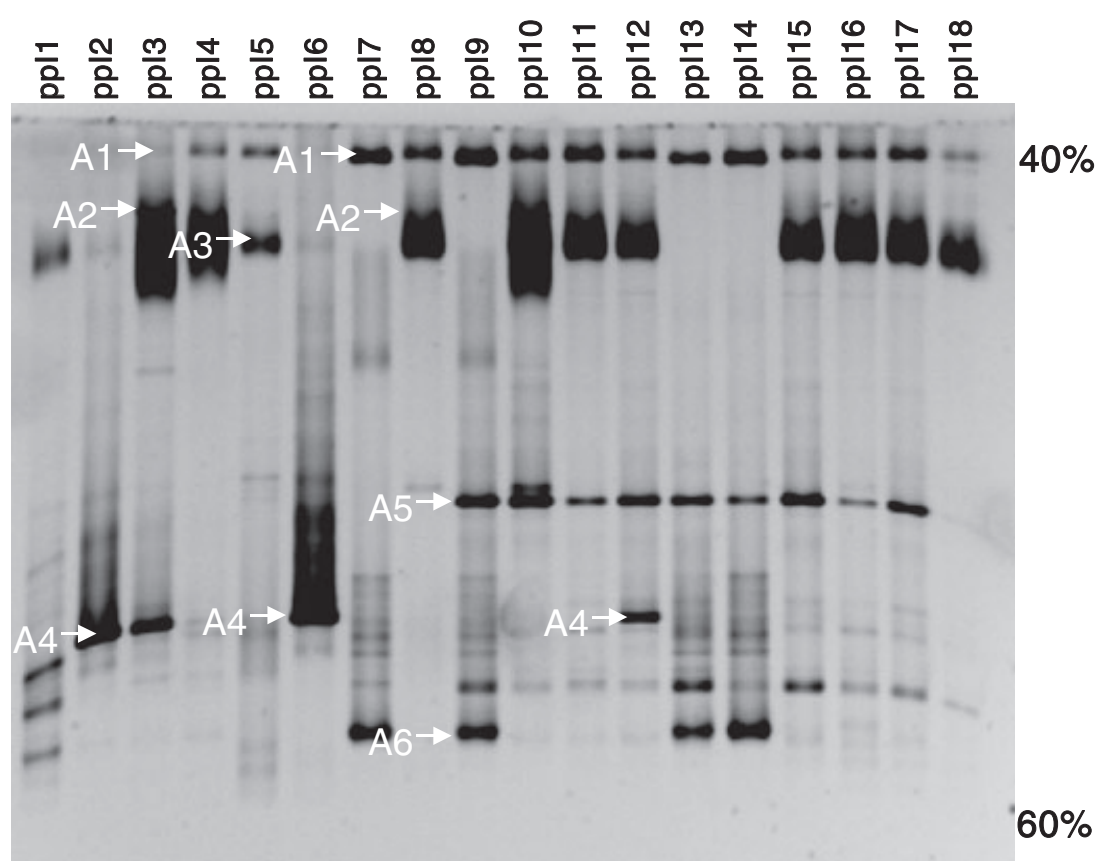

Fig. 1. Bacterial diversity associated with Cacopsylla pyri adult individuals. Example of DGGE profiles, in $7 \%$ polyacrylamide gels with $40 \%$ to $60 \%$ denaturation gradients, of partial 16S rRNA bacterial genes amplified from DNA extracted from whole insects collected in 2008-2009 from pear orchards in Valle d'Aosta and Piedmont, Italy. Names over the lanes refer to the ID of the tested individuals. The identity of sequences of bands marked with arrows is given in Table 1 according to the band ID (A1-A6). 
Table 1. Identification of microorganisms associated with C. pyri adults according to DGGE profiles.

\begin{tabular}{|c|c|c|c|c|c|}
\hline $\begin{array}{l}\text { Band } \\
\text { ID }\end{array}$ & Most related species & $\begin{array}{l}\text { Accession } \\
\text { No. }\end{array}$ & $\begin{array}{l}\text { Nucleotide } \\
\text { identity (\%) }\end{array}$ & Putative classification & $\begin{array}{l}\text { No. } \\
\text { positives }\end{array}$ \\
\hline A1 & 'Ca. C. ruddii' & AF211131 & $100(570 / 570 \mathrm{bp})$ & Gammaproteobacteria & $30 / 36$ \\
\hline A2 & 'Ca. P. pyri' & AJ542543 & $99(519 / 520 \mathrm{bp})$ & Mollicutes, Acholeplasmatales & $7 / 36$ \\
\hline A3 & S-endosymbiont of C. pyricola & AF286125 & $98(527 / 533 \mathrm{bp})$ & Gammaproteobacteria, Enterobacteriales & $24 / 36$ \\
\hline A4 & 'Ca. L. asiaticus' & AB480102 & 98 (499/507 bp) & Alphaproteobacteria; Rhizobiales & $13 / 36$ \\
\hline A5 & Ralstonia sp. & AB503703 & $100(530 / 530 \mathrm{bp})$ & Betaproteobacteria, Burkholderiales & $16 / 36$ \\
\hline A6 & $\begin{array}{l}\text { Sodalis-related secondary endosymbiont } \\
\text { of the weevil Curculio sikkimensis }\end{array}$ & AB517595 & $96(511 / 528 \mathrm{bp})$ & Gammaproteobacteria, Enterobacteriales & $4 / 36$ \\
\hline
\end{tabular}

a. Number of individuals positive for the presence of the specific band in DGGE analysis compared with the total number of individuals analysed. Band ID is defined according to Fig. 1.

the genus Ralstonia have been reported from xylem tissues of the clove tree as well as from the insect Hindola spp. in Indonesia (Vaneechoutte et al., 2004). Band A6 had $96 \%$ identity with both the Sodalis-allied secondary endosymbiont of Curculio sikkimensis (Heller) (AB517595) and the primary endosymbiont of Sitophilus oryzae (L.) (AF548139).

Interestingly, band A4 had $98 \%$ identity with ' $\mathrm{Ca}$. L. asiaticus' (AB480102). Bacteria in the genus ' $\mathrm{Ca}$. Liberibacter' are known as plant pathogens causing HLB in different citrus varieties, as well as zebra chip and psyllid yellows in solanaceous crops (Teixeira et al., 2005; Bové, 2006; Hansen et al., 2008; Abad et al., 2009; AdkarPurushothama et al., 2009; Liefting et al., 2009; Secor et al., 2009; Tyler et al., 2009). Since liberibacters have not yet been reported in pear psyllids and in Europe, efforts were concentrated on the characterization of the phylogenetic position and the evaluation of the prevalence of the newly discovered ' $C a$. Liberibacter' species together with 'Ca. P. pyri' in C. pyri individuals and pear plants.

\section{Phylogeny of the newly discovered 'Ca. Liberibacter' sp.}

The almost full length of the 16S rRNA gene (1410 bp) as well as the 16S-23S rRNA gene ITS sequences were obtained from different $C$. pyri individuals by combining the specific Lib223F and Lib451R primers with the universal eubacterial primers as described in Experimental procedures. When aligned by BLAST, the 16S rRNA sequence was shown to share $96 \%$ similarity with ' $\mathrm{Ca}$. L. americanus' (AY742824, EU754742) and 94\% with 'Ca. L. africanus' (L22533, EU754741) and 'Ca. L. solanacearum' (EU834130). In the phylogenetic tree constructed on the basis of the almost full length of the 16S rRNA gene (Fig. 2), the newly discovered ' $\mathrm{Ca}$. Liberibacter' clustered in a separate branch from the other four liberibacter species, suggesting that it represents a new species in the genus ' $\mathrm{Ca}$. Liberibacter'. This conclusion was confirmed by the analysis of the 16S-23S rRNA ITS sequence. DNA amplified with primers Lib223F and ITSREub was directly sequenced in both directions, resulting in a 613-bp-long sequence different from the 591, 620 and $1184 \mathrm{bp}$ ITS of 'Ca. L. americanus' (FJ263693), 'Ca. L. asiaticus' isolate GuangXi-GL-1 (DQ778016) and 'Ca. L. asiaticus' from Florida (FJ263704) respectively. The ITS sequence has the same length as the ITS region from the ' $C a$. L. africanus' strain Mpumalanga-UPCRI-06-0071 (EU754741). The ITS region was found to contain the sequences for two tRNA genes: alanine and isoleucine. The comparison of the ITS region from the newly discovered ' $\mathrm{Ca}$. Liberibacter' with that of the other ' $\mathrm{Ca}$. Liberibacter' species resulted in $80 \%$ identity with the partial sequence of ' $\mathrm{Ca}$. L. solanacearum' (EU834130) followed by $79 \%$ with 'Ca. L. americanus' (FJ263693). Also, in the phylogenetic tree constructed based on the ITS sequences, the newly discovered ' $\mathrm{Ca}$. Liberibacter' clustered in a separate branch from the other species (Fig. 3).

These results indicate that the liberibacter identified in $C$. pyri represents a new species for which the name ' $\mathrm{Ca}$. Liberibacter europaeus' is proposed.

\section{Localization of 'Ca. L. europaeus' and 'Ca. P. pyri' in} adults of $\mathrm{C}$. pyri

Fluorescent in situ hybridization (FISH) using specific probes for 'Ca. L. europaeus' and 'Ca. P. pyri' allowed their detection in different organs of the insect body. 'Candidatus L. europaeus' was detected in the midgut (Fig. 4A). Both bacteria were colocalized in Malpighian tubules (Fig. 4B) and salivary glands (Fig. 4C). No specific signals were observed in the male (Fig. 4D) and female (Fig. 4E) reproductive organs tested here with all four specific probes. FISH signals with liberibacter/phytoplasma-specific probes were (when present) analogous to those observed by using bacterial probe EUB338, whereas no signals were observed in tissues treated with RNase or in the absence of the probes. 


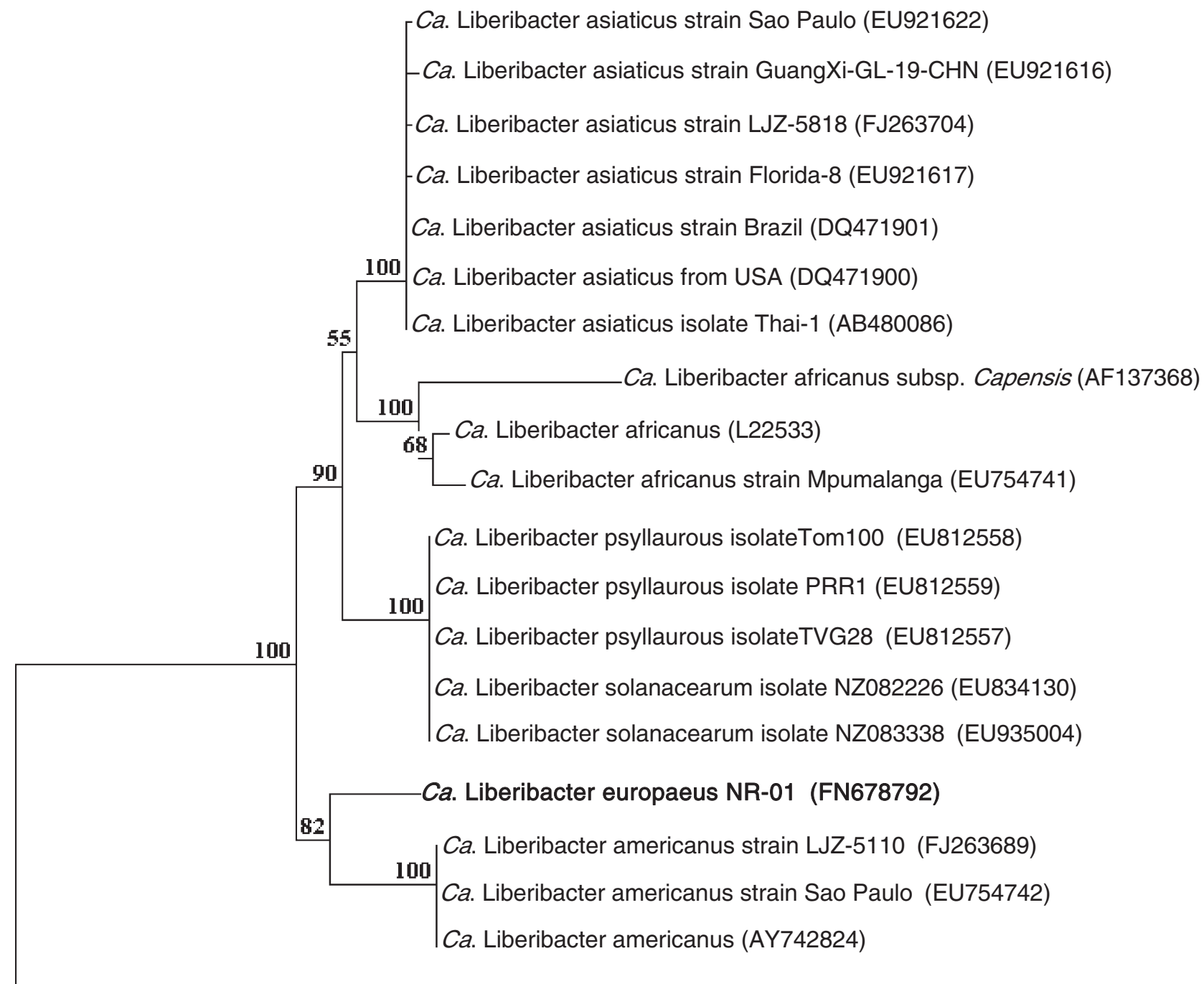

Sinorhizobium arboris strain LMG14917 (AM181752)

Fig. 2. Phylogenetic affiliation of the almost entire 16S rRNA gene of 'Candidatus Liberibacter europaeus' constructed using the TREECON $1.3 \mathrm{~b}$ package. Numbers at each node represent percentages of bootstrap replications calculated from 1000 replicate trees.

Prevalence of 'Ca. L. europaeus' and 'Ca. P. pyri' in C. pyri and pear plants

Specific nested PCR approaches were used to detect ' $C a$. L. europaeus' and apple proliferation (AP) group phytoplasmas in insects and plants. The restriction fragment length polymorphism (RFLP) analyses with Sspl and Rsal on nested PCR amplicons confirmed in all cases the identity of the phytoplasma as ' $\mathrm{Ca}$. P. pyri'. We screened using nested PCRs 238 C. pyri individuals and 227 pear plant samples recovered from the field for the presence of the liberibacter and the phytoplasma.
'Candidatus L. europaeus' and 'Ca. P. pyri' were detected in $51.7 \%(123 / 238)$ and $26.5 \%$ $(63 / 238)$ of the individuals respectively. Simultaneous infection with both bacteria was detected in $14.3 \%$ $(34 / 238)$ of the individuals. Out of 131 C. pyri male individuals, $54.2 \% \quad(71 / 131), 27.5 \% \quad(36 / 131)$ and $15.3 \%$ (20/131) were infected by 'Ca. L. europaeus', 'Ca. P. pyri' and both the bacteria respectively. Among the 107 C. pyri females tested, 45.8\% (49/107), $25.2 \%(27 / 107)$ and $13.1 \%$ (14/107) were infected by 'Ca. L. europaeus', 'Ca. P. pyri' and both the bacteria respectively. 
0.02

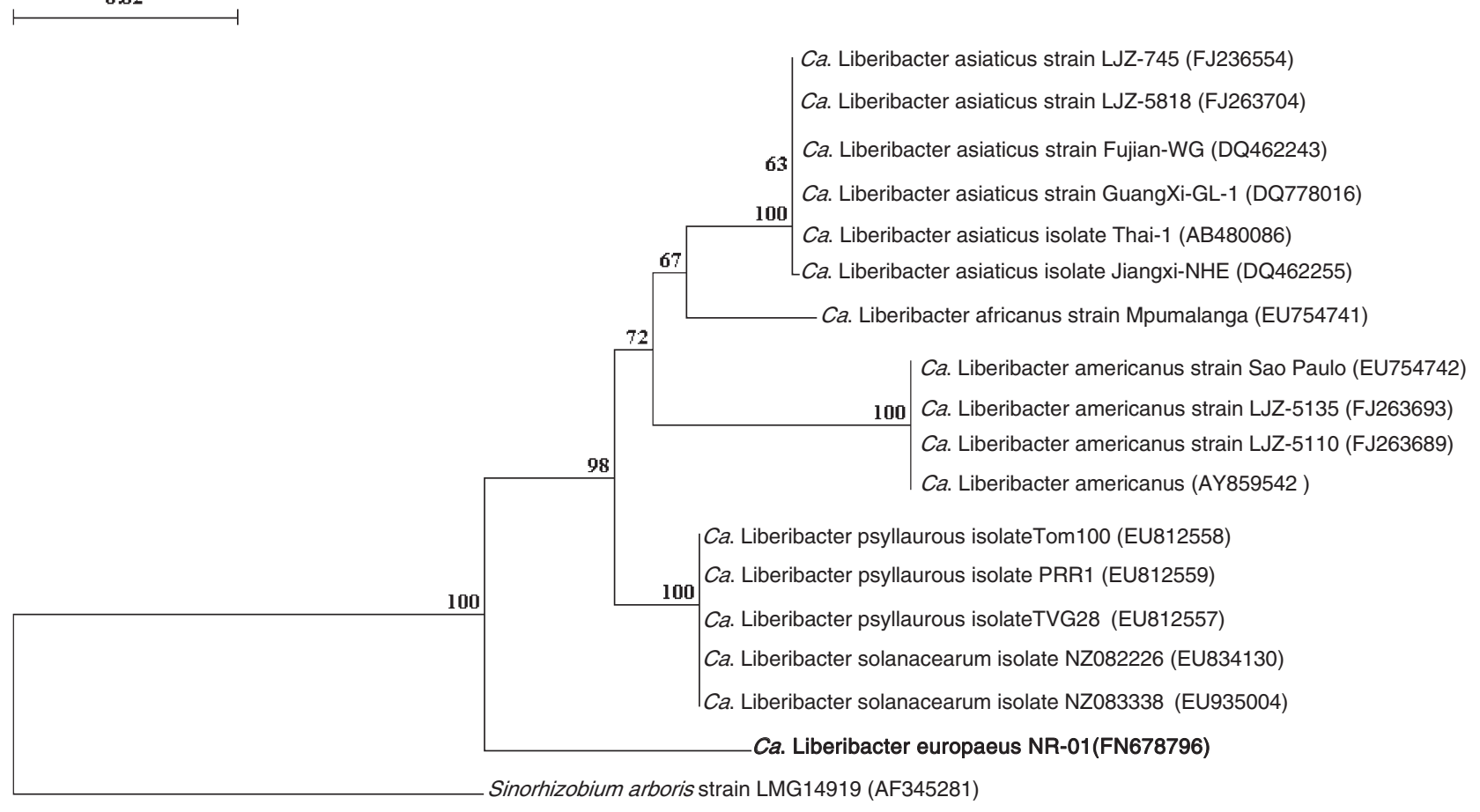

Fig. 3. Phylogenetic affiliation of the entire 16S-23S ITS of the 'Candidatus Liberibacter europaeus' constructed using the TREECON 1.3b package. Numbers at each node represent percentages of bootstrap replications calculated from 1000 replicate trees.

Out of the 227 field pear plant samples tested, ' $\mathrm{Ca}$. L. europaeus' and 'Ca. P. pyri' were detected in 50.2\% (114/ $227)$ and $45.3 \%(103 / 227)$ of the plants respectively. Both the bacteria were simultaneously present in $22.9 \%$ (52/ 227) of the plants.

Nested PCR is a sensitive method for detecting low copy number templates. However, it does not provide the target copy number, as real-time RT-PCR does. To determine the 16S rRNA gene copy number of ' $\mathrm{Ca}$. L. europaeus' and 'Ca. P. pyri', quantitative real-time RT-PCR was performed on 76 C. pyri individuals and 98 pear plants. Among the 76 C. pyri individuals tested, $72.4 \%$
$(55 / 76)$ were positive for the presence of the liberibacter, $51.3 \%(39 / 76)$ for the phytoplasma and $35.5 \%$ (27/76) for both bacteria. The higher percentage of positive samples obtained with the quantitative real-time RT-PCR than with the nested PCR can be explained by a higher sensitivity achieved with the former, as shown for the detection of 'Ca. L. americanus' (Teixeira et al., 2008). The range of 'Ca. L. europaeus' 16S rRNA gene copies varied from $8.31 \times 10^{0}$ to $1.13 \times 10^{9}$ copies per $C$. pyri individual. Taking into account that there are three copies of rRNA operons in the genome of ' $\mathrm{Ca}$. Liberibacter' (Duan et al., 2009), there were between $2.77 \times 10^{0}$ and $3.77 \times 10^{8}$ cells

Fig. 4. Localization of 'Candidatus Liberibacter europaeus' and 'Candidatus Phytoplasma pyri' cells in different organs of C. pyri.

A. Midgut. (a) Interferential contrast micrograph showing a gut portion of an adult individual. (b) CLSM image of FISH of the insect gut after hybridization with the FITC-labelled Eub338 probe targeting all eubacteria. (c) CLSM image showing same gut portion after hybridization with the Cy5-labelled probes Lib223 and Lib451 specific for 'Ca. L. europaeus'.

B. Malpighian tubules. The image of a Malpighian tubule pictured by interferential contrast is shown in (a); the tubule lumen is visible. After hybridization with the eubacterial Eub338 probe, the tube lumen appears to be full of bacterial cells (b), belonging to 'Ca. L. europaeus', as observed after hybridization with the Cy5-labelled Liberibacter probes (c) and a much weaker signal was obtained after hybridization with the phytoplasma-specific Cy3-labelled probes (d).

C. Salivary glands of $C$. pyri. (a) Interferential contrast micrograph of a salivary gland lobe. (b-d) CLSM image of FISH of the same salivary gland portion after hybridization with the FITC-labelled universal Eub338 probe (b), with the Cy5-labelled probes Lib223 and Lib451 specific for 'Ca. L. europaeus' (c) and with the Cy3-labelled probes PDF1 and PDF2 specific for 'Ca. P. pyri' (d).

D. Male gonads of $C$. pyri. (a) Interferential contrast micrograph of $C$. pyri testes. (b-d) CLSM image of FISH of the same testes after hybridization with the FITC-labelled universal Eub338 probe (b), the Cy5-labelled probes Lib223 and Lib451 specific for 'Ca. L. europaeus' (c) and the Cy3-labelled probes PDF1 and PDF2 specific for 'Ca. P. pyri' (d).

E. Female gonads of $C$. pyri. (a) Interferential contrast micrograph of $C$. pyri ovary. (b-d) CLSM image of FISH of the same ovary after hybridization with the FITC-labelled universal Eub338 probe (b), the Cy5-labelled probes Lib223 and Lib451 specific for 'Ca. L. europaeus' (c) and the Cy3-labelled probes PDF1 and PDF2 specific for 'Ca. P. pyri' (d). 

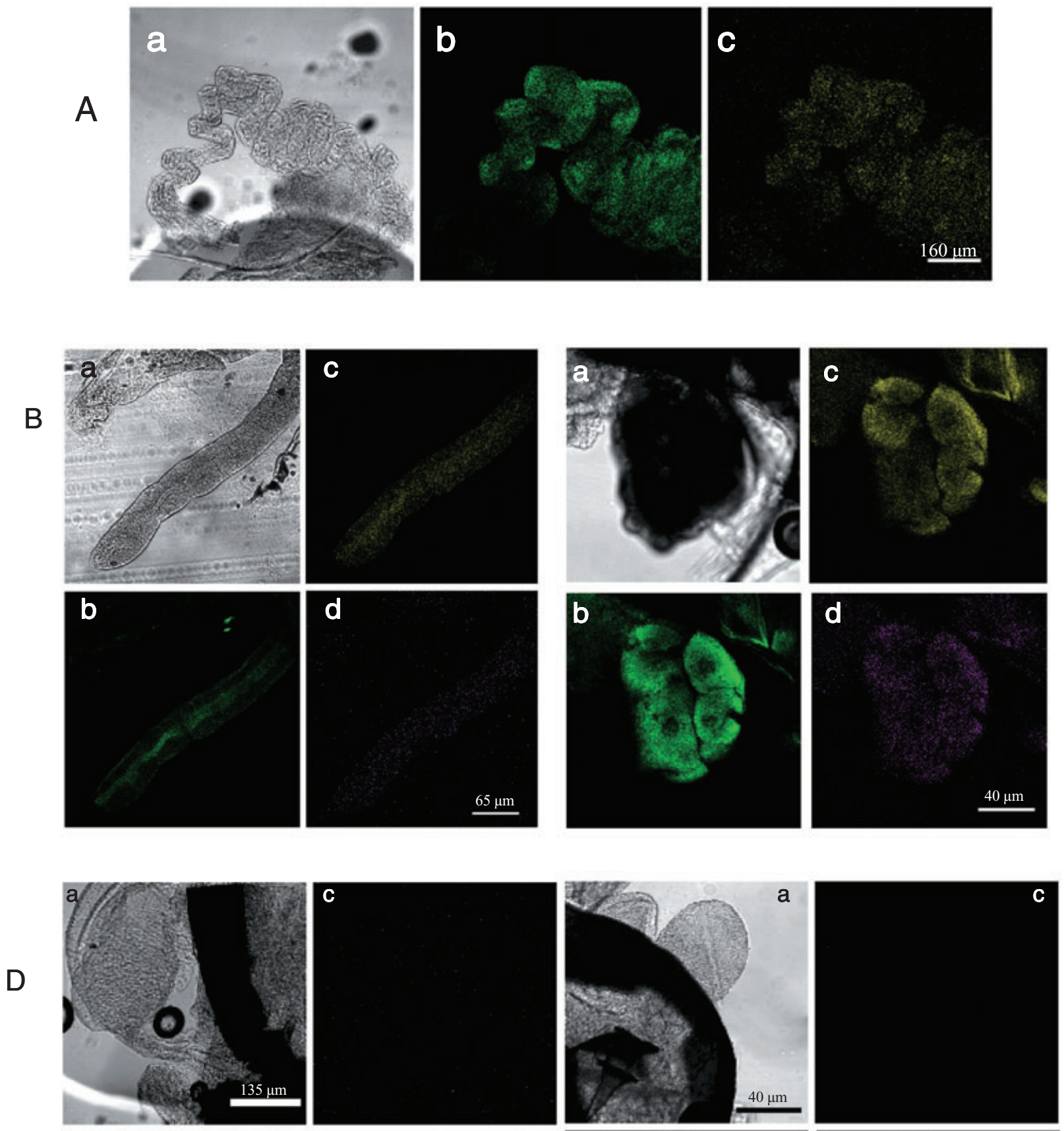

C

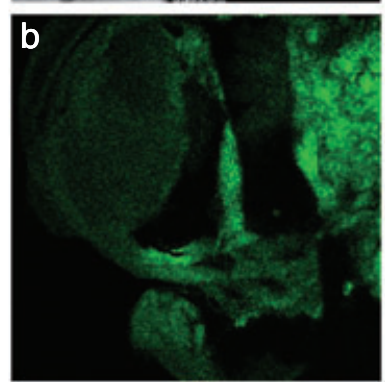

d
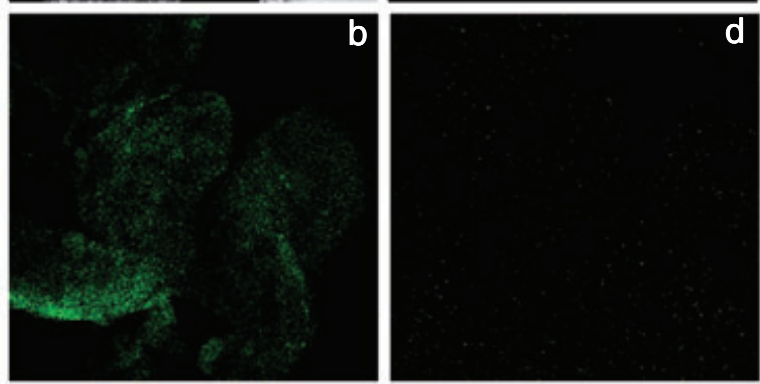
of 'Ca. L. europaeus' per C. pyri individual. The range of 'Ca. P. pyri' 16S rRNA gene copies varied from $2.86 \times 10^{1}$ to $1.7 \times 10^{6}$ copies per $C$. pyri individual. Taking into account that there are two copies of rRNA operons in the genome of 'Ca. P. pyri' (Schneider and Seemüller, 1994), there were between $1.43 \times 10^{1}$ and $8.50 \times 10^{5}$ cells of 'Ca. P. pyri' per $C$. pyri individual. Based on the range of eubacterial 16S rRNA gene copies varying between $4.12 \times 10^{4}$ and $4.96 \times 10^{9}$, 'Ca. L. europaeus' was shown to represent between $0.001 \%$ and $29.8 \%$ of the total bacterial community of the insect, whereas ' $\mathrm{Ca}$. P. pyri' corresponded to $0.001-34.4 \%$ of the insect microbiome. Among the 98 pear plants tested, 91.8\% (90/98) and $84.7 \%$ (83/98) were infected with 'Ca. L. europaeus' and 'Ca. P. pyri', respectively, whereas $78.6 \%$ (77/98) were positive for the presence of both bacteria. Between $6.03 \times 10^{2}$ and $1.62 \times 10^{8} 16 \mathrm{~S}$ rRNA gene copies of ' $\mathrm{Ca}$. L. europaeus' and between $6.32 \times 10^{3}$ and $1.05 \times 10^{11}$ gene copies of ' $\mathrm{Ca}$. P. pyri' were present per gram of plant tissue. Based on the number of 16S rRNA gene operons in the genomes of ' $\mathrm{Ca}$. Liberibacter' and the PD phytoplasma, there were between $2.01 \times 10^{2}$ and $5.40 \times 10^{7}$ cells of ' $\mathrm{Ca}$. L. europaeus' and between $3.16 \times 10^{3}$ and $5.26 \times 10^{10}$ cells of 'Ca. P. pyri' per gram of plant tissue.

\section{Transmission of 'Ca. L. europaeus' and 'Ca. P. pyri' to young pear plants by C. pyri}

Among the 100 field psyllids employed for the transmission trials, DNA was extracted from 62 individuals that showed by nested PCR percentages of infection of $70.2 \%, 64.5 \%$ and $43.6 \%$ for 'Ca. L. europaeus', 'Ca. P. pyri' and both the bacteria respectively. Among the 20 psyllids confined in each cage, the percentage of infection ranged from $50 \%$ to $100 \%$ for ' $C a$. L. europaeus', $50 \%$ to $83 \%$ for 'Ca. P. pyri' and $30 \%$ to $80 \%$ for both bacteria. Two months after the inoculation access period, the first screening of the pear seedlings for the presence of both bacteria was performed and resulted in two out of the 10 plants exposed to $C$. pyri positive for the presence of only 'Ca. L. europaeus'. All the plants were re-examined 15 days later and the same results were obtained. The presence of the phytoplasma was detected 3 months after the inoculation access period in one plant that was previously negative for ' $C a$. L. europaeus'. In contrast, none of the samples showing the liberibacter infection in the earlier tests was positive for this bacterium. PCR screenings performed during the following 3 months (fourth to sixth month after the inoculation access period) resulted in the same infection pattern and no leaves' co-infection events (of the same plant leaf by both bacteria) were shown to happen. The first reddening symptoms were observed on the plant infected with 'Ca. P. pyri' 4 months after the acquisition access period, whereas none of the two liberibacter-infected plants showed any symptom of disease even after 6 months of the monitoring period.

\section{Discussion}

Relatively simple community patterns showing six major different bands were observed by PCR-DGGE analysis of the 16S rRNA gene among the different individuals of $C$. pyri analysed. We concentrated our attention on the bacterium that showed a nucleotide identity with ' $\mathrm{Ca}$. L. asiaticus' and on its association with the pathogen ' $\mathrm{Ca}$. $\mathrm{P}$. pyri', because of the emerging importance of liberibacters as plant pathogens. Indeed, bacteria in this genus, quarantine agents in the Mediterranean area, have been known to have an economically important impact, such as pathogens of citrus trees in Africa, Asia and America and solanaceous crops in America and New Zealand. An almost full-length (1410 bp) sequence of the 16S rRNA gene was obtained by the extension of the ' $\mathrm{Ca}$. $\mathrm{L}$. asiaticus'-related band detected in the DGGE analysis. This sequence showed $96 \%$ similarity to ' $\mathrm{Ca}$. L. americanus' (AY742824, EU754742) and 94\% to both 'Ca. L. africanus' (L22533, EU754741) and 'Ca. L. solanacearum' (EU834130, EU935004). Stackebrandt and Goebel (1994) considered $97.5 \%$ similarity in the $16 \mathrm{~S}$ rRNA gene sequence as a minimum to cluster two bacteria in the same species. The percentage similarity in the case of the new liberibacter and ' $\mathrm{Ca}$. L. americanus' (with which the liberibacter found in $C$. pyri has the highest nucleotide identity) was $96 \%$, indicating that the two liberibacters represent two different species. Indeed, the phylogenetic tree inferred from the $1410 \mathrm{bp}$ 16S rRNA gene sequence (Fig. 2) clustered the bacterium in a separate branch from the four reported species. This phylogenetic position was also confirmed by the 16S-23S rRNA ITS region. The 16S-23S rRNA ITS sequence was $613 \mathrm{bp}$

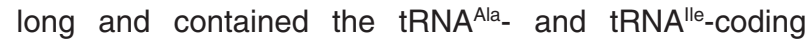
genes. The 16S-23S rRNA ITS of 'Ca. L. asiaticus' (Jagoueix et al., 1997), 'Ca. L. americanus' (Teixeira et al., 2008), 'Ca. L. africanus ssp. capensis' (Garnier et al., 2000) and 'Ca. L. solanacearum' (Liefting et al., 2009) also contained tRNA ${ }^{\text {lle }}$ and tRNA ${ }^{\text {Ala }}$, whereas that of 'Ca. L. africanus' was reported to contain only tRNA $A^{\text {Ala }}$ (Jagoueix et al., 1997). Compared with the 16S-23S rRNA ITS of the four other ' $\mathrm{Ca}$. Liberibacter' species, a sequence identity of $80 \%$ and $79 \%$ with ' $C a$. L. solanacearum' and 'Ca. L. americanus' was found respectively. It has been reported that the ITS sequence does not vary much within a given liberibacter species with isolates of the same species having either identical or very similar intergenic sequences (Jagoueix et al., 1997; Subandiyah et al., 2000b; Ding et al., 2009; Tomimura et al., 2009; Wen et al., 2009). However, a low similarity value was found when the 16S-23S rRNA ITS sequences of two 
different species were compared. For example, the recently described species 'Ca. L. solanacearum' had $80 \%, 79 \%$ and $78 \%$ sequence similarity with the $16 \mathrm{~S}-23 \mathrm{~S}$ rRNA ITS sequences from 'Ca. L. asiaticus', 'Ca. L. americanus' and 'Ca. L. africanus' respectively. 'Candidatus L. solanacearum' had $80 \%$ similarity with the newly found sequence from $C$. pyri, which confirms the results based on the 16S rRNA gene sequence comparisons and indicates that the new liberibacter is a novel species. Also, in the phylogenetic tree inferred based on the ITS sequence, the bacterium clusters in a branch separated from the other four species. Hence, based on the 16S rRNA gene, the 16S-23S rRNA ITS sequences and the novel host range, the newly discovered sequence should be considered a novel species in the candidate genus ' $\mathrm{Ca}$. Liberibacter' to which we attributed the name ' $\mathrm{Ca}$. L. europaeus' because this is the first time that this genus is reported to occur in Europe. Altogether, both for the 16S rRNA gene and for 16S-23S rRNA ITS sequences, the percentage nucleotide identity shows that ' $C a$. $L$. europaeus' is more closely related to ' $\mathrm{Ca}$. L. solanacearum' and ' $\mathrm{Ca}$. L. americanus' than to ' $\mathrm{Ca}$. L. asiaticus' and ' $\mathrm{Ca}$. L. africanus'. This phylogenetic position was also confirmed and reflected in the phylogenetic trees constructed based on the 16S rRNA gene sequences (Fig. 2) and 16S-23S rRNA ITS sequences.

The localization of 'Ca. L. europaeus' and 'Ca. P. pyri' in different organs of $C$. pyri was determined by FISH using specific probes. 'Candidatus L. europaeus' was detected in the midgut and both bacteria were colocalized in Malpighian tubules and in the salivary glands, whereas no specific signals were observed from the testes and ovaries with the four specific probes used (Fig. 4A-C). These results suggest that, similar to 'Ca. P. pyri' (Hogenhout et al., 2008), once acquired by $C$. pyri from infected plants, 'Ca. L. europaeus' multiplies in different organs of the insect and mainly in the salivary glands, before being transmitted to other plants during insect feeding events. In addition to this horizontal transmission during feeding events, Hansen and colleagues (2008) reported that ' $\mathrm{Ca}$. Liberibacter psyllaurous' is also vertically transmitted by $B$. cockerelli to the offspring at different rates depending on the host plant on which the psyllid was reared. In contrast, in the case of $D$. citri, laboratory experiments showed no transovarial transmission of ' $C a$. L. asiaticus' (Hung et al., 2004). Our FISH experiments did not detect liberibacter in the gonads, suggesting that it is not vertically transmitted by $C$. pyri. However, in light of the abovementioned studies, further experiments on larger numbers of $C$. pyri individuals and populations must be performed to definitely exclude a vertical transmission route.

The presence of 'Ca. L. europaeus' and 'Ca. P. pyri' was assessed in different adults of $C$. pyri and pear plant samples. Being present in about $52 \%$ of the insects tested, 'Ca. L. europaeus' was more prevalent than the phytoplasma detected in less than $27 \%$ of the 238 C. pyri individuals analysed. An infection rate of $45.2 \%$ for ' $C a$. $L$. asiaticus' has been reported in $D$. citri individuals from Indonesia (Subandiyah et al., 2000a). In contrast, Manjunath and colleagues (2008) reported that ' $\mathrm{Ca}$. L. asiaticus' was present in only $10.5 \%$ (105 out of 1200 nymphs and adults) of $D$. citri individuals tested in Florida. This divergence could be because of the inoculum sources (e.g. evergreen versus deciduous plants) and/or variable efficiencies in the liberibacter uptake in relation to age effects. Among the 227 plant samples tested by conventional and nested PCR, similar infection rates of $50.2 \%$ and $45.3 \%$ for ' $\mathrm{Ca}$. L. europaeus' and 'Ca. P. pyri' were observed, respectively, whereas $22.9 \%$ of the plants were positive for the simultaneous presence of both bacteria.

Quantitative real-time RT-PCR analysis allowed the detection of less than three cells (or genome copies) of liberibacter per individual of $C$. pyri and 200 cells per gram of plant tissue. In the case of the phytoplasma, a minimum of about 14 cells per $C$. pyri individual and $3.16 \times 10^{3}$ cells per gram of plant tissue were detected respectively. The real-time RT-PCR data showed that ' $\mathrm{Ca}$. L. europaeus' was present in a high density in both insects and plants reaching up to $10^{8}$ cells per individual and up to $10^{7}$ cells per gram of plant tissue respectively. Similar results were also found for ' $\mathrm{Ca}$. L. asiaticus' in previous studies performed on $D$. citri in Florida when $3 \%$ of the infected population was shown to carry up to $10^{8}$ cells per insect (Duan et al., 2009). In a recent study (Li et al., 2009), an average of $10^{10}$ ' $\mathrm{Ca}$. L. asiaticus' genomes per gram of tissue were detected in both the root samples and the above-ground portions of naturally infected citrus trees. In contrast, an average of $10^{7}$ genome copies of ' $\mathrm{Ca}$. $\mathrm{L}$. americanus' was detected in symptomatic sweet orange plants (Teixeira et al., 2008).

Since 'Ca. L. europaeus' was detected both in $C$. pyri salivary glands (as shown by FISH experiments) and pear plant phloem tissue, transmission trials were set up, under outdoor conditions, to confirm the occurrence of the transmission of the bacterium from insects to healthy plants. The results obtained showed that ' $C a$. L. europaeus' could be transmitted to healthy plants during insect feeding events. Although the presence of the bacterium was confirmed in the test plant tissues, we observed no particular symptoms. The absence of symptoms in pear plants (both from the field and the psyllid-inoculated ones under laboratory conditions) could be because of the endophyte nature of ' $\mathrm{Ca}$. L. europaeus' in pear plants and/or pears might represent an intermediate reservoir of the bacterium that explicate virulence towards other plants when properly transmitted. One fact that supports a role as an endophyte is the presence of the liberibacter in about $92 \%$ of 
the pear plants tested by real-time RT-PCR (90/98) without any disease symptom. If the liberibacter was an endophyte, it could exert a protective effect on the plant because of the competitive displacement of the phytoplasma by competition for the same niche, the phloem cells. Further experimental trials are ongoing to better study such a hypothesis.

In conclusion, the analysis of the microbial community within $C$. pyri allowed the identification of a novel species of liberibacter that is transmitted to pear plants. The results highlight that the diversity of liberibacters is higher than previously reported, with regard to the insect and plant host range and virulence. This bacterium was found to infect pear plants at a high titre without disease symptoms in the field-collected samples or in the laboratory inoculated plants, suggesting an endophytic rather than a pathogenic nature. However, based on the history of liberibacters as plant pathogens, further investigations on these bacteria from plants and insects from other climatic areas and on their transmission and potential virulence should be performed to confirm a virulence-free nature.

\section{Experimental procedures}

\section{Insect collection, plant material and DNA isolation}

Adults of $C$. pyri (131 males and 107 females) were collected from pear trees between 2008 and 2009 from eight different pear orchards in the Valle d'Aosta (one orchard) and Piedmont (seven orchards) regions, north-western Italy, in areas affected by PD disease. The samples were kept in pure ethanol at $-20^{\circ} \mathrm{C}$ until DNA extraction. Single $C$. pyri individuals were washed three times in distilled water before total DNA was isolated by sodium dodecyl sulfate-proteinase K-cethyltrimethyl ammonium bromide treatment (Sambrook et al., 1989) with one modification: insects were ground in $500 \mu \mathrm{l}$ of TE buffer, $\mathrm{pH} 8$, using sterile pestles and fine quartz powder. The precipitated DNA was resuspended in $30 \mu \mathrm{l}$ of TE buffer, $\mathrm{pH} 8$ and kept at $-20^{\circ} \mathrm{C}$ until use. Pear branches from 227 plants were collected from the same eight pear orchards as C. pyri. DNA was extracted from $100 \mathrm{mg}$ (wet weight) of plant phloem tissue previously ground with liquid nitrogen in a sterile mortar, according to the DNeasy Plant Mini Kit protocol (Qiagen, Italy) instructions. DNA was eluted in $100 \mu \mathrm{l}$ of elution buffer and kept at $-20^{\circ} \mathrm{C}$ until used.

\section{PCR amplification and DGGE analysis of the microbiota associated with adults of $\mathrm{C}$. pyri}

For PCR-DGGE analysis, primers GC357F, containing a 40 bp GC clamp, and 907R were used to amplify a $550 \mathrm{bp}$ fragment of the 16S rRNA gene using as template total DNA isolated from single $C$. pyri individuals as previously described (Sass et al., 2001). Seven per cent [of a 37:1 acrylamide:bisacrylamide mixture in $1 \times$ Tris-acetate-EDTA (TAE) buffer] polyacrylamide gels with a denaturing gradient of $40-60 \%$ ( $100 \%$ denaturing polyacrylamide was defined as $7 \mathrm{M}$ urea and $40 \%$ formamide) were made with a gradient maker (Bio-Rad, Milan, Italy) according to the manufacturer's guidelines. For polymerization $50 \mu \mathrm{l}$ of $10 \%$ APS solution (ammonium-persulfate, $\mathrm{w} / \mathrm{v}$ ) and $7 \mu$ of TEMED were added. Gels were run for $16 \mathrm{~h}$ at $90 \mathrm{~V}$ in $1 \times$ TAE buffer at a constant temperature of $60^{\circ} \mathrm{C}$ in a D-Code electrophoresis system (Bio-Rad). The gels were stained for $30 \mathrm{~min}$ in 1× TAE buffer containing $1 \times$ SYBR Green (Invitrogen, Milan, Italy) and then washed in distilled water for $\mathbf{3 0}$ min. Visualization and digital image recording were performed with GelDoc 2000 apparatus (Bio-Rad, Milan, Italy) using the Quantity one software (Bio-Rad).

\section{Sequencing of DGGE bands}

DGGE bands were excised from the gel using a sterile blade, eluted at $37^{\circ} \mathrm{C}$ for $6 \mathrm{~h}$ in $50 \mu \mathrm{l}$ of MilliQ water and kept at $-20^{\circ} \mathrm{C}$ until reamplification. Primers 357F (without GC clamp) and 907R were used for the reamplification of 1-9 $\mu$ l (based on the intensity of the DGGE band) of the eluted DNA fragments. PCR products were sent to Primm (Primm srl San Raffaele Biomedical Science Park, Milan, Italy) for purification and sequencing. Sequencing was performed using the $357 F$ primer as in DGGE but without the GC clamp. The resulting sequences were compared with the sequence database at the National Center for Biotechnology Information using BLAST (http://www.ncbi.nlm.nih.gov/BLAST) (Altschul et al., 1990; Johnson et al., 2008).

Based on the sequences of the DGGE bands, the sequence of the $16 \mathrm{~S}$ rRNA of the new ' $\mathrm{Ca}$. Liberibacter' species was extended by two additional specific PCRs using two specific primers designed in this study. These two primers, named Lib223F, 5'-CCAGGGCTCAACCCTGG AACG-3' and Lib451R, 5'-CTACGCCACTGAATGGTAAAA$3^{\prime}$, respectively, corresponding to positions 538-558 and 766-786 of the 16S rRNA gene of ' $\mathrm{Ca}$. L. solanacearum' (NZ082226), were used in combination with the universal reverse 1494R (5'-CTACGGCTACCTTGTTACGA-3') and the forward 27F (5'-AGAGTTTGATCCTGGCTCAG-3') primers to amplify the flanking regions at the $5^{\prime}$ and $3^{\prime}$ ends of the DGGE fragment. After amplification, the fragments were sequenced in both directions and aligned with the original sequence from the DGGE fragment. The final sequence obtained by assembling the two $16 \mathrm{~S}$ rRNA gene contigs was then used to analyse the phylogenetic position of the bacterium. A partial 16S rRNA gene sequence was also obtained by combining the specific and universal primers from pear plant samples using template total DNA isolated from plant phloem.

\section{Sequencing of the 16S-23S rRNA intergenic transcribed spacer}

To confirm the taxonomic position of the bacterium characterized based on the 16S rRNA gene sequence, sequencing of the 16S-23S rRNA ITS was also performed. The specific primer Lib223F was used in combination with the universal primer ITSREub (5'-GCCAAGGCATCCACC-3') (Cardinale et al., 2004) for the amplification of the 16S-23S ITS 
sequences. Based on previous works reporting only one ITS haplotype for the genus ' $\mathrm{Ca}$. Liberibacter', PCR products were directly sequenced in both directions with primers Lib223F and ITSREub. The obtained ITS sequence was then used to characterize the phylogenetic affiliation of the bacterium.

\section{Phylogenetic analysis}

Both partial 16S rRNA and full-length 16S-23S rRNA ITS sequences of the new liberibacter species identified in $C$. pyri and pear-infected leaves were subjected to BLAST analysis and aligned with close relatives, as well as with other unrelated eubacterial sequences. Phylogenetic analyses were performed using the Jukes and Cantor distance estimation with the TREECON 1.3b package (Van de Peer and De Wachter, 1994). A 50\% majority rule bootstrap consensus tree (1000 replicates) was generated.

\section{Fluorescent in situ hybridization}

Fluorescent in situ hybridization analysis was carried out on tissues dissected from field-collected $C$. pyri adults in a sterile saline solution. The dissected organs were fixed for $2 \mathrm{~min}$ at $4^{\circ} \mathrm{C}$ in $4 \%$ paraformaldehyde and washed in PBS. All hybridization experiment steps were performed as previously described (Crotti et al., 2009), using the specific fluorescent probes Lib223 (5'-CGTTCCAGGGTTGAGCCCTGG-3') and Lib451 (5'-CTACGCCACTGAATGGTAAAA-3'), matching with the $16 \mathrm{~S}$ rRNA of ' $\mathrm{Ca}$. L. europaeus' and PDF1 (5'-GACCATAGACTTATTAAACCG-3') and PDF2 (5'CTCAGGCGGAGTACTTAATGC-3'), targeting the $16 \mathrm{~S}$ rRNA of 'Ca. P. pyri'. Probes Lib223 and Lib451 were labelled at the $5^{\prime}$ end with the fluorochrome Cy5 (indodicarbocyanine, absorption/emission at 650/670 nm), whereas probes PDF1 and PDF2 were marked with the fluorochrome Cy3 (indocarbocyanine, absorption/emission at $550 / 570 \mathrm{~nm}$ ). As a positive control for the hybridization experiment, a universal bacterial probe EUB388 labelled with fluorescein isothiocyanate (FITC, absorption/emission at $494 / 520 \mathrm{~nm}$ ) was also used (Fuchs et al., 1998), by applying the same treatments described in Crotti and colleagues (2009). The probe EUB338 is routinely used as a universal bacterial probe even though several phyla are not completely covered (Daims et al., 1999). Control experiments were performed by applying either the treatment of slides with RNase before the probe hybridization step or the absence of the probe. After hybridization, the samples were mounted in antifading medium and then observed in a laser scanning confocal microscope SP2AOBS (Leica).

\section{Prevalence of 'Ca. L. europaeus' and 'Ca. P. pyri'}

The Lib223F and Lib451R specific primers amplified a $228 \mathrm{bp}$ fragment of the newly discovered sequence. This primer pair was used in heminested PCRs to search ' $\mathrm{Ca}$. L. europaeus' from insect individuals and plants that did not give an amplification in direct conventional PCR using the universal primer 27F and the specific one Lib451R. PCR amplifications were performed in a $25 \mu \mathrm{l}$ reaction mixture containing $1 \times$ PCR buffer (Invitrogen), $0.12 \mathrm{mM}$ of each dNTP, $0.3 \mu \mathrm{M}$ of each primer, $1 \mathrm{U}$ of Taq polymerase (Invitrogen) and $1 \mu \mathrm{l}$ of DNA template. The cycling conditions were as follows (for both direct and nested PCRs): $94^{\circ} \mathrm{C}$ for $4 \mathrm{~min}$; 10 cycles of $94^{\circ} \mathrm{C}$ for $1 \mathrm{~min}, 61^{\circ} \mathrm{C}$ for $30 \mathrm{~s}$ and $72^{\circ} \mathrm{C}$ for $1 \mathrm{~min} ; 20$ cycles of $94^{\circ} \mathrm{C}$ for $30 \mathrm{~s}, 56^{\circ} \mathrm{C}$ for $45 \mathrm{~s}$ and $72^{\circ} \mathrm{C}$ for $1 \mathrm{~min}$; and $7 \mathrm{~min}$ at $72^{\circ} \mathrm{C}$.

To search 'Ca. P. pyri', conventional PCRs with phytoplasma universal primers $\mathrm{P} 1 / \mathrm{P} 7$ and nested PCR with primers fO1/rO1, specific for AP group phytoplasmas, were performed using the previously described conditions (Lorenz et al., 1995; Schneider et al., 1995). Afterwards, $7 \mu \mathrm{l}$ of the nested PCR products were digested $\left(37^{\circ} \mathrm{C}, 3 \mathrm{~h}\right)$ using $3 \mathrm{U}$ of each of the endonucleases Sspl and Rsal. The restriction products were then separated on a $1.5 \%$ agarose gel, and 'Ca. P. pyri' was identified based on the RFLP profile. A total of 238 C. pyri individuals, including those examined by DGGE, and 227 pear plants were screened by PCR.

\section{Quantitative real-time RT-PCR for 'Ca. L. europaeus' and 'Ca. P. pyri'}

Quantitative real-time RT-PCRs were performed on the Chromo4 real-time detector (Bio-Rad) using Lib223F/ Lib451R, PDF for1 (5'-CGGTTTAATAAGTCTATGGTC-3')/ PDF rev1 (5'-CTCAGGCGGAGTACTTAATGC-3'), primer sets designed in this study or bacterial universal primers 357F (5'-CTACGGGAGGCAGCA G-3') and 907R (5'CCGTCAATTCCTTTGAGTTT- $3^{\prime}$ ). To realize standard curves, a $781 \mathrm{bp}$ fragment of the 16S rRNA gene of ' $\mathrm{Ca}$. L. europaeus' amplified by PCR with primers 27F/Lib451R and a fragment of about $1800 \mathrm{bp}$ fragment obtained with primers P1/P7 (Lorenz et al., 1995) were cloned using a pGEM T-easy Vector Cloning Kit (Promega). Following the calculation of the 16S rRNA gene copies of bacteria and ' $\mathrm{Ca}$. L. europaeus', the liberibacter-to-bacterial 16S rRNA gene copy ratio (LBR) was calculated and used as an estimate of the relative abundance of ' $\mathrm{Ca}$. $\mathrm{L}$. europaeus' in the bacterial community associated with different individuals of $C$. pyri. Similarly, the phytoplasma-to-bacterial 16S rRNA gene copy ratio (PBR) was also calculated. For pear plants, the results were expressed as 16S rRNA gene copy numbers (of liberibacter and phytoplasma) per gram of plant phloem tissue, since LBR and PBR could not be estimated because chloroplast and mitochondrial DNA are preferentially amplified when the bacterial primer set used in this study was applied for the amplification of bacterial DNA from plants (Overbeek et al., 2006; Tyler et al., 2009). The detection limit of the real-time RT-PCR was $8.31 \times 10^{\circ} 16 \mathrm{~S}$ rRNA gene copies of 'Ca. L. europaeus' (corresponds to about three cells of the bacterium) per C. pyri individual.

\section{Transmission of 'Ca. L. europaeus' to pear leaves by C. pyri}

Adults of $C$. pyri were collected from pear orchards where 'Ca. L. europaeus' was found to be highly present both in plants and insects, to ensure the presence of naturally infected individuals among those used for the trial. Cacopsylla pyri individuals were caged onto young pear plants (3-6 
months old) obtained from seeds and that had tested negative for the presence of ' $\mathrm{Ca}$. L. europaeus' by real-time RT-PCR. The insects were confined in five batches of 20 (10 females and 10 males), inside $200 \times 200 \times 300 \mathrm{~mm}$ Plexiglas cages with two sides and a top made of a fine gauze (30/10 net) and containing two test plants. The psyllids were left to feed on the young plants for 1 week after which they were removed and kept in pure ethanol at $-20^{\circ} \mathrm{C}$ until used for PCR screening. The test plants were also treated with an insecticide (a. i. thiametoxam, trade name Actara $®, 30 \mathrm{~g} \mathrm{hl}^{-1}$ ) to kill putative remaining psyllids. Afterwards, the treated seedlings were maintained inside a psyllid-proof screen house (20/10 net) for all the trial period. Two other young pear plants obtained from seeds and that were tested negative for the presence of ' $\mathrm{Ca}$. L. europaeus' by real-time RT-PCR were caged and treated in the same way as the test plants but with no exposure to psyllids and used as controls. Two months after the insects' removal, one leaf sample from each plant was recovered every 15 days for a total period of 4 months. Leaf samples were used for DNA extraction and specific PCR screening for the presence of ' $\mathrm{Ca}$. $\mathrm{L}$. europaeus' and ' $\mathrm{Ca}$. P. pyri'.

\section{Sequence accession numbers}

The sequences of the 16S rRNA gene and 16S-23S rRNA ITS of 'Ca. L. europaeus' (named strain NR-01) from $C$. pyri (a male individual named ppl6 captured in Valle d'Aosta, Italy) have been deposited in the DDBJ-EMBL-GenBank databases under the Accession Nos FN678792 and FN678796 respectively.

\section{Acknowledgements}

Partial financial contribution came from the Italian Ministry for Research (MIUR), in the ambit of projects PRIN 2007 'Caratterizzazione del microbiota associato a Scaphoideus titanus e Hyalesthes obsoletus, cicaline vettrici di fitoplasmi nella vite ed isolamento e studio della localizzazione di batteri acetici simbionti'. E.C., C.C. and D.D. benefited from travel grants from Cost Action FA0701: 'Arthropod Symbiosis: From Fundamental Studies to Pest and Disease Management'. N.R. was supported by the Università degli Studi di Torino and the Regione Piemonte in the ambit of the project 'Studio dei microrganismi simbionti di artropodi vettori di patologie umane e vegetali e di nuove strategie di Controllo Simbiotico della trasmissione' (assegno cofinanziato dalla Regione Piemonte - Rep. N. 12607 del 30/07/2007).

\section{References}

Abad, J.A., Bandla, M., French-Monar, R.D., Liefting, L.W., and Clover, G.R.G. (2009) First report of the detection of 'Candidatus Liberibacter' species in zebra chip diseaseinfected potato plants in the United States. Plant Dis 93: 108.

Adkar-Purushothama, C.R., Quaglino, F., Casati, P., Ramanayaka, J.G., and Bianco, P.A. (2009) Genetic diversity among 'Candidatus Liberibacter asiaticus' isolates based on single nucleotide polymorphisms in $16 S$
rRNA and ribosomal protein genes. Ann Microbiol 59: 681-688.

Altschul, S.F., Gish, W., Miller, W., Myers, E.W., and Lipman, D.J. (1990) Basic local alignment search tool. J Mol Biol 215: 403-410.

Ben Khalifa, M., Marrakchi, M., and Fakhfakh, H. (2007) 'Candidatus Phytoplasma pyri' infections in pear orchards in Tunisia. J Plant Pathol 89: 269-272.

Bové, J.M. (2006) Huanglongbing: a destructive, newlyemerging, century-old disease of citrus. J Plant Pathol 88: 7-37.

Cardinale, M., Brusetti, L., Quatrini, P., Borin, S., Puglia, A.M., Rizzi, A., et al. (2004) Comparison of different primer sets for use in automated ribosomal intergenic spacer analysis of complex bacterial communities. Appl Environ Microbiol 70: 6147-6156.

Clark, M.A., Baumann, L., Thao, M., Moran, N.A., and Baumann, P. (2001) Degenerative minimalism in the genome of a psyllid endosymbiont. J Bacteriol 183: 18531861.

Conci, C., Rapisarda, C., and Tamanini, L. (1993) Annotated catalogue of the Italian Psylloidea. First part (Insecta Homoptera). Atti Accad Roveretana Degli Agiati 245 Ser VII II,B: 33-136.

Crotti, E., Damiani, C., Pajoro, M., Gonella, E., Rizzi, A., Ricci, I., et al. (2009) Asaia, a versatile acetic acid bacterial symbiont, capable of cross-colonizing insects of phylogenetically distant genera and orders. Environ Microbiol 11: 3252-3264.

Daims, H., Brühl, A., Amann, R., Schleifer, K.H., and Wagner, M. (1999) The domain-specific probe EUB338 is insufficient for the detection of all Bacteria: development and evaluation of a more comprehensive probe set. Syst Appl Microbiol 22: 434-444.

Ding, F., Deng, X., Hong, N., Zhong, Y., Wang, G., and Yi, G. (2009) Phylogenetic analysis of the citrus Huanglongbing (HLB) bacterium based on the sequences of 16S rDNA and 16S/23S rDNA intergenic regions among isolates in China. Eur J Plant Pathol 124: 495-503.

Duan, Y., Zhou, L., Hall, D.G., Li, W., Doddapaneni, H., Lin, $\mathrm{H}$., et al. (2009) Complete genome sequence of citrus Huanglongbing bacterium, 'Candidatus Liberibacter asiaticus' obtained through metagenomics. Mol Plant Microbe Interact 22: 1011-1020.

Fuchs, B.M., Wallner, G., Beisker, W., Schwippl, I., Ludwig, W., and Amann, R. (1998) Flow cytometric analysis of the in situ accessibility of Escherichia coli 16S rRNA for fluorescently labeled oligonucleotide probes. Appl Environ Microbiol 42: 4973-4982.

Garnier, M..S., Jagoueix-Eveillard, P.R., Cronje, H.F., Roux, L., and Bové, J.M. (2000) Genomic characterization of a liberibacter present in an ornamental rutaceous tree, Calodendrum capense, in the Western Cape Province of South Africa. Proposal of 'Candidatus Liberibacter africanus subsp. capensis. Int J Syst Evol Microbiol 50: 21192125.

Hansen, A.K., Trumble, J.T., Stouthamer, R., and Paine, T.D. (2008) New Huanglongbing species, 'Candidatus Liberibacter psyllaurous' found to infect tomato and potato, is vectored by the psyllid Bactericera cockerelli (Sulc). Appl Environ Microbiol 74: 5862-5865. 
Hogenhout, S.A., Oshima, K., Ammar, el-D., Kakizawa, S., Kingdom, H.N., and Namba, S. (2008) Phytoplasmas: bacteria that manipulate plants and insects. Mol Plant Pathol 9: 403-423.

Hung, T.H., Hung, S.C., Chen, C.N., Hsu, M.H., and Su, H.J. (2004) Detection by PCR of Candidatus Liberibacter asiaticus, the bacterium causing citrus huanglongbing in vector psyllids: application to the study of vector-pathogen relationships. Plant Pathol 53: 96-102.

Jagoueix, S., Bove, J.M., and Garnier, M. (1997) Comparison of the $16 \mathrm{~S} / 23 \mathrm{~S}$ ribosomal intergenic regions of 'Candidatus Liberobacter asiaticum' and 'Candidatus Liberobacter africanum', the two species associated with citrus huanglongbing (greening) disease. Int J Syst Bacteriol 47: 224-227.

Johnson, M., Zaretskaya, I., Raytselis, Y., Merezhuk, Y., McGinnis, S., and Madden, T.L. (2008) NCBI BLAST: a better web interface. Nucleic Acids Res $\mathbf{3 6}$ (web server issue): W5-W9.

Li, W., Levy, L., and Hartung, J.S. (2009) Quantitative distribution of 'Candidatus Liberibacter asiaticus' in citrus plants with citrus huanglongbing. Phytopathology 99: 139-144.

Liefting, L.W., Weir, B.S., Pennycook, S.R., and Clover, G.R. (2009) 'Candidatus Liberibacter solanacearum', associated with plants in the family Solanaceae. Int J Syst Evol Microbiol 59: 2274-2276.

Lopes, S.A., Frare, G.F., Bertolini, E., Cambra, M., Fernandes, N.G., Ayres, A.J., et al. (2009) Liberibacters associated with citrus huanglongbing in Brazil: 'Candidatus Liberibacter asiaticus' is heat tolerant, 'Ca. L. americanus' is heat sensitive. Plant Dis 93: 257-262.

Lorenz, K.H., Schneider, B., Ahrens, U., and Seemuller, E. (1995) Detection of the apple proliferation and pear decline phytoplasmas by PCR amplification of ribosomal and nonribosomal DNA. Phytopathology 85: 771-776.

Manjunath, K.L., Halbert, S.E., Ramadugu, C., Webb, S., and Lee, R.F. (2008) Detection of 'Candidatus Liberibacter asiaticus' in Diaphorina citri and its importance in the management of citrus huanglongbing in Florida. Phytopathology 98: 387-396.

Micheletti, S., Slater, R., and Gillham, M. (2005) Susceptibility to abamectin of pear Psylla populations collected from Spain, Italy and France. European baselines, 2004. Commun Agric Appl Biol Sci 70: 593-599.

Overbeek, L., van Vuurde, J., and van Elsas, J. (2006) Application of molecular fingerprinting techniques to explore the diversity of bacterial endophytic communities. In Soil Biology Vol. 9 - Microbial Root Endophytes. Schulz, B.J.E., Boyle, C.J.C., and Sieber, T.N. (eds). Berlin, Heidelberg, Germany: Springer-Verlag, pp. 338-335.

Sambrook, J., Fritsch, E.F., and Maniatis, T. (1989) Molecular Cloning: A Laboratory Manual, 2nd edn. Cold Spring Harbor, NY, USA: Cold Spring Harbor Laboratory Press.

Sass, A.M., Sass, H., Coolen, M.J., Cypionka, H., and Overmann, J. (2001) Microbial communities in the chemocline of a hypersaline deep-sea basin (Urania basin, Mediterranean Sea). Appl Environ Microbiol 67: 5392-5402.

Schneider, B., and Seemüller, E. (1994) Presence of two sets of ribosomal genes in phytopathogenic Mollicutes. Appl Environ Microbiol 60: 3409-3412.

Schneider, E., Seemüller, E., Smart, C.D., and Kirkpatrick, B.C. (1995) Phylogenetic classification of plant pathogenic mycoplasma-like organism or phytoplasmas. In Molecular and Diagnostic Procedures in Mycoplasmology, Vol. I. Razin, S., and Tully, J.G. (eds). San Diego, CA, USA: Academic Press, pp. 369-380.

Secor, G.A., Rivera, V.V., Abad, J.A., Lee, I.-M., Clover, G.R.G., Liefting, L.W., et al. (2009) Association of 'Candidatus Liberibacter solanacearum' with zebra chip disease of potato established by graft and psyllid transmission, electron microscopy, and PCR. Plant Dis 93: 574583.

Seemüller, E., and Schneider, B. (2004) 'Candidatus Phytoplasma mali', 'Candidatus Phytoplasma pyri' and 'Candidatus Phytoplasma prunorum', the causal agents of apple proliferation, pear decline and European stone fruit yellows, respectively. Int J Syst Evol Microbiol 54: 12171226.

Spaulding, A.W., and von Dohlen, C.D. (1998) Phylogenetic characterization and molecular evolution of bacterial endosymbionts in psyllids (Hemiptera: Sternorrhyncha). Mol Biol Evol 15: 1506-1513.

Spaulding, A.W., and von Dohlen, C.D. (2001) Psyllid endosymbionts exhibit patterns of co-speciation with hosts and destabilizing substitutions in ribosomal RNA. Insect Mol Biol 10: 57-67.

Stackebrandt, E., and Goebel, B.M. (1994) Taxonomic note: a place for DNA-DNA reassociation and 16S rRNA sequence analysis in the present species definition in Bacteriology. Int J Syst Bacteriol 44: 846-849.

Subandiyah, S., Nikoh, N., Tsuyumu, S., Somowiyarjo, S., and Fukatsu, T. (2000a) Complex endosymbiotic microbiota of the citrus psyllid Diaphorina citri (Homoptera: Psylloidea). Zool Sci 17: 983-989.

Subandiyah, S., Iwanami, T., Tsuyumu, S., and Leki, H. (2000b) Comparison of 16S rDNA and 16S/23S intergenic region sequences among citrus greening organisms in Asia. Plant Dis 84: 15-18.

Tedeschi, R., Bosco, D., and Alma, A. (2002) Population dynamics of Cacopsylla melanoneura (Homoptera: Psyllidae), a vector of apple proliferation phytoplasma in northwestern Italy. J Econ Entomol 95: 544-551.

Teixeira, D.C., Danet, J.L., Eveillard, S., Martins, E.C., Cintra de Jesus, W., Jr, Yamamoto, P.T., et al. (2005) Citrus huanglongbing in São Paulo State, Brazil: PCR detection of the 'Candidatus' Liberibacter species associated with the disease. Mol Cell Probe 19: 173-179.

Teixeira, D.C., Saillard, C., Couture, C., Martins, E.C., Wulff, N.A., Eveillard-Jagoueix, S., et al. (2008) Distribution and quantification of 'Candidatus Liberibacter americanus', agent of huanglongbing disease of citrus in São Paulo State, Brasil, in leaves of an affected sweet orange tree as determined by PCR. Mol Cell Probes 22: 139-150.

Thao, M.L., Moran, N.A., Abbot, P., Brennan, E.B., Burckhardt, D.H., and Baumann, P. (2000) Cospeciation of psyllids and their prokaryotic endosymbionts. Appl Environ Microbiol 66: 2898-2905.

Tomimura, K., Miyata, S., Furuya, N., Kubota, K., Okuda, M., Subandiyah, S., et al. (2009) Evaluation of genetic diversity among 'Candidatus Liberibacter asiaticus' isolates collected in Southeast Asia. Phytopathology 99: 1062-1069.

Trowbridge, R.E., Dittmar, K., and Whiting, M.F. (2006) Identification and phylogenetic analysis of Arsenophonus- and 
Photorhabdus-type bacteria from adult Hippoboscidae and Streblidae (Hippoboscoidea). J Invertebr Pathol 91: 64-68. Tyler, H.L., Roesch, L.F., Gowda, S., Dawson, W.O., and Triplett, E.W. (2009) Confirmation of the sequence of 'Candidatus Liberibacter asiaticus' and assessment of microbial diversity in Huanglongbing-infected citrus phloem using a metagenomic approach. Mol Plant Microbe Interact 22: 1624-1634.

Van de Peer, Y., and De Wachter, R. (1994) TREECON for Windows: a software package for the construction and drawing of evolutionary trees for the Microsoft Windows environment. Comput Appl Biosci 10: 569-570.
Vaneechoutte, M., Kämpfer, P., Baere, T.D., Falsen, E., and Verschraegen, G. (2004) Wautersia gen. nov., a novel genus accommodating the phylogenetic lineage including Ralstonia eutropha and related species, and proposal of Ralstonia [Pseudomonas] syzygii (Roberts et al. 1990) comb. nov. Int J Syst Evol Microbiol 54: 317327.

Wen, A., Mallik, I., Alvarado, V.Y., Pasche, J.S., Wang, X., Li, W., et al. (2009) Detection, distribution, and genetic variability of 'Candidatus Liberibacter' species associated with zebra complex disease of potato in North America. Plant Dis 93: 1102-1115. 